\title{
地震時市街地火災の延焼速度に関する基礎的研究 BASIC STUDY ON FIRE SPREAD SPEED OF SEISMIC FIRE ON URBAN AREA
}

\author{
難 波 義 郎*, 保野 健治郎** \\ Yoshiro NAMBA and Kenjiro YASUNO
}

\begin{abstract}
In this paper, we have dealt with the fire spread speed at the time of the earthquake. We analyzed the data from the Great Hanshin-Awaji Earthquake. It has been expressed with the factor such as the district of urban area to be burnt, the complete collapse rate, the wind velocity and also time. From the burn-out area and the fire front length, the mean value of fire spread speed have been obtained. Furthermore the predictions of fire spread speed that are the mean value, the maximum value, and so forth have been examined. And we showed that we are able to predict the fire spread speed at the time of earthquake by using our fire spread model.
\end{abstract}

Keywords: earthquake, fire, fire spread speed, prediction

地震, 火災, 延焼速度, 予測

\section{1.はじめに}

地震時市街地火災の延焼速度（m/h）については, 関東大震災以 後, 多くの実験と研究がなされており，それらの研究成果を都市防 火計画に導入すべく，種々の構想が検討されている1-3)。

本研究では，延焼面積を焼損区域面積，全壊率，風速および時間 などの因子をもって表現し，その焼損面積 $A\left(\mathrm{~m}^{2}\right)$ と火面周長 $S_{\text {nean }}(\mathrm{m})$ から延焼速度の平均値 $\left(V_{\text {rean }}\right)$ を求め, この $V_{\text {rean }}$ より, 各時間ごとの延 焼速度の最大值 $\left(V_{\max }(\right.$ 予測 $\left.)\right)$ ， および延焼速度の実測值の最大值 $V_{\max }$ (実測)などの諸関倸について基礎的な研究をしたものである。

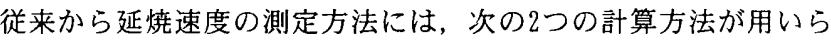

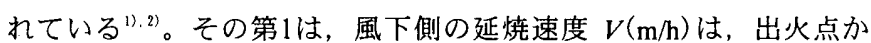
ら風下へ向かって焼け止まり点まで測った距離 $K(\mathrm{~m})$ をその時間 $x$ c (min)で除した平均速度として,

$$
V=K\left(x_{\mathrm{c}}\right) /\left(x_{\mathrm{c}} / 60\right)
$$

とするものである。ここで, 延焼距離 $K$ を時間 $x$ の関数として $K(x)$ のように表現している。また，第2の方法はある時間ごとの平均速 度を $t(\mathrm{~min})$ 刻みで求めることにし, 延焼速度 $V$ を時間 $x$ の関数で 表現して,

$$
V(x)=\frac{K(x+t / 2)-K(x-t / 2)}{t / 60}
$$

とするものである。本研究では, 式(2)によって表現される距離延 焼速度を単に延焼速度と呼ぶ。

\section{2. 延焼速度の予測について}

筆者らは, 出火からの経過時間 $x$ における焼損面積 $A$ を表わす 延焼モデを式(3)のように表わしている ${ }^{1-16) 。 ~}$

$$
\begin{aligned}
& A=\frac{G+n \cdot \varepsilon}{1+\exp \left\{-a_{1}\left(x-c_{1}\right)\right\}}-\frac{G+n \cdot \varepsilon}{1+\exp \left(a_{1} \cdot c_{1}\right)} \\
& \varepsilon=G /\left(1+\exp \left(a_{1} \cdot c_{1}\right)\right) \\
& a_{1}=f(v / G) \\
& c_{1}=f(G / v)
\end{aligned}
$$

* 近畿大学工学部建築学科 助教授・工博

** 近畿大学工学部建築学科 教授. I博
Assoc. Prof., Kinki University, Department of Architecture, Faculty of Engineering, Dr. Eng.

Prof., Kinki University, Department of Architecture, Faculty of Engineering, Dr. Eng. 
ここに，A：焼損面積( $\mathrm{m}^{2}$; ある時点 $x$ における空地などを含む延 焼区域の面積), $x$ : 出火からの経過時間 (min), $G$ : 地震時火災のよ うな放置火災の場合は最終焼損面積, 平常時のように消火活動をす る場合は，延焼危険のある区域面積 ( $\left.\mathrm{m}^{2} ， た た ゙ し ， A \leqq G\right) ， v ：$ 風 速 $(\mathrm{m} / \mathrm{s}), \mathrm{n}: \mathrm{n}$ は $1 \leqq \mathrm{n}<3$ として使用する。一般にnは, $1.3<\mathrm{n}$ く2程度となる。また， $a_{1} ， c_{1}$ ：各火災事例では定数であるが, 風速 や全壊率等の影響を受けるもので, 兵庫県南部地震にお打る大火災 の資料より， $\mathrm{a}_{1}, \mathrm{C}_{1}$ を $\mathrm{v} ， \mathrm{G}$ および $\mathrm{D}$ (全壊率)の関数として表して (いる ${ }^{14)}$ 。

さて, 式(3)を $x$ で微分すると式(4)となる ${ }^{16)}$ 。

$d A / d x=\mathrm{a}_{1} \cdot A(1-A /(\mathrm{G}+\mathrm{n} \cdot \varepsilon))$

また, 火面周長上の延焼速度の平均値 $\left(V_{\operatorname{men}}: \mathrm{m} / \mathrm{min}\right)$ は, 次式 で表示できる。

$$
V_{\text {mean }}=(d A / d x) / \ddot{S_{\text {mean }}}
$$

ここに, $S_{\text {nean }}$ : 出火がらの経過時間” $x$ での平均的な火面周長であ る。 $S_{\text {men }}$ は焼損面積 $\mathrm{A}$ の関数であり,$x$ の関数として表される。

平均的な火面周長 $S_{\text {mean }}$ を兵庫県南部地震の神戸市大火について 求め, これらを式 (5)に代入して, これら大火の経過時間に対応し た火面周長上の延焼速度の平均値 $\left(V_{\mathrm{m} \text { man }}\right)$ および最大値 $\left(V_{\operatorname{mxx}}\right)$ を 求めることについて検討する。

\section{3. 兵庫県南部地震市街地大火の延焼速度と予測について}

神戸市消防局と東京消防庁の調査資料より, 調查中で不明な場所 は除外して分析の対象とした地区の全焼損面積. (敷地および街路を

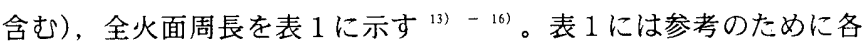
地区の建物の全壊率および平均風速を示した。全壊率は日本都市計 画学会および日本建築学会が調查した阪神・淡路大震災被害実態緊 急調査被災度別建物分布状況図（霞災復興都市づくり特別委員会） をもとに焼失街区の被害程度が周辺街区から推定されたものであ り，木造または防火木造建物が多数を占める 2 階以下の建物の全罗 率（全壊または大破）を示している。平均風速は神戸市消防局（三 宮）の記録を使用して求めている ${ }^{13)}-16 \%$ 。

今回の神戸市の地震時火災は, 焼損面積 $A\left(\mathrm{~m}^{2}\right)$ と時間 $x(\mathrm{~min})$ と の関係は S カーブとなり, 式(3)の曲線関係がほぼ適用される。非 線形最小 2 乗法による各調査地区の適用結果を表 2 に示す。

次に, 兵庫県南部地震における表 1 における全調查地区について 延焼動態図の延焼等時曲線よりプラニメーターで計測した火面周長

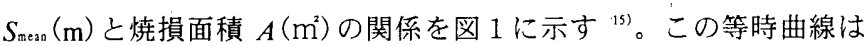
各地区の火災で時間間隔は必ずしも一定ではないが，それぞれの火 災で数組のデータが得られた。そして，その関倸を非線形最小 2 乗 法で求めたものが式(6)である。

$$
S_{\text {mean }}=1.11 \cdot A^{0.655} \quad(\mathrm{R}=0.958)
$$

ここに; 焼損面積 $A$ は， $10 ， 000<A<120 ， 000 \mathrm{~m}^{2}$ 程度である。 そして, 全調査地区を対象とする火面周長上の延焼速度の平均値
表 1 調査地区のデー夕概要

\begin{tabular}{|c|c|c|c|c|}
\hline 調查地区 & 全焼損面積 & 全火面周長 & 風速 & 全壞率 \\
\hline $\mathrm{T} 1$ & 111,440 & 2,130 & 1.57 & 0.714 \\
\hline $\mathrm{T} 2$ & 36,830 & 1,115 & 1.18 & 0.667 \\
\hline $\mathrm{T} 3$ & 17,537 & 616 & 0.95 & 0.460 \\
\hline $\mathrm{T} 4$ & 30,681 & 1,071 & 1.96 & 0.309 \\
\hline $\mathrm{T} 5$ & 39,200 & 1,154 & 0.89 & 0.485 \\
\hline $\mathrm{T} 6$ & 51,593 & 1,400 & 0.92 & 0.431 \\
\hline $\mathrm{T} 8$ & 10,427 & 388 & 1.64 & 0.587 \\
\hline
\end{tabular}

表 2 各調査地区の式(3)の係数

\begin{tabular}{|c|c|c|c|c|}
\hline 調查地区 & $G+n \varepsilon$ & $a_{1}$ & $c_{1}$ & 重相関係数 : $\mathrm{R}$ \\
\hline $\mathrm{T} 1$ & 122,820 & 0.00714 & 707 & 0.944 \\
\hline $\mathrm{T} 2$ & 39,445 & 0.00875 & 233 & 0.998 \\
\hline $\mathrm{T} 3$ & 31,872 & 0.00850 & 46.7 & 0.999 \\
\hline $\mathrm{T} 4$ & 32,458 & 0.0186 & 186 & 0.998 \\
\hline $\mathrm{T} 5$ & 55,638 & 0.0128 & 110 & 0.999 \\
\hline $\mathrm{T} 6$ & 53,257 & 0.0205 & 167 & 0.999 \\
\hline $\mathrm{T} 8$ & 10,675 & 0.0626 & 86.9 & 0.999 \\
\hline
\end{tabular}

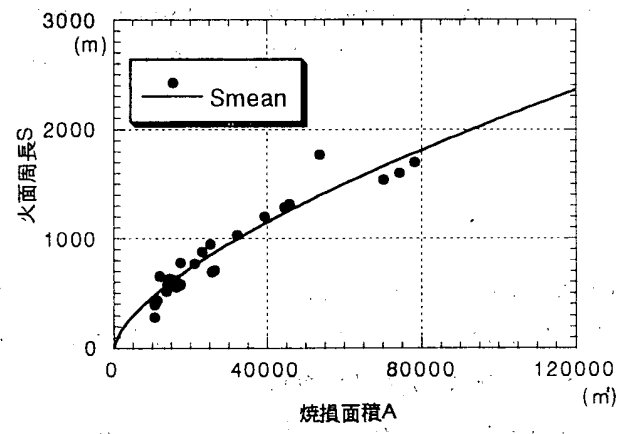

図 1 火面周長と焼損面積の関係 ${ }^{15)}$

（ $\left.V_{\text {mean }} ; \mathrm{m} / \mathrm{min}\right)$ は, 式 (4)，式 (5)および式 (6)より式(7)のようにな る。

$$
\begin{aligned}
V_{\text {mean }} & =\mathrm{a}_{1} \cdot A(1-A /(\mathrm{G}+\mathrm{n} \cdot \varepsilon)) /\left(1.11 \cdot A^{0.055}\right) \\
& =0.900 \cdot \mathrm{a}_{1} \cdot A^{0.345}(1-A /(\mathrm{G}+\mathrm{n} \cdot \varepsilon))
\end{aligned}
$$

次に, 各調查地区の延焼速度の平均値 $\left(V_{\text {mean }}\right)$ を各々のデータから 求めることにする。火面周長は次式のように表示して, 非線形最小 2 乗法により求めた各調査地区の火面周長の係数值を表 3 に示す。

$$
S_{\mathrm{mena}}=\mathrm{m}_{1} \cdot A^{\mathrm{m} 2} \quad\left(こ こ に \mathrm{~m}_{1}, \mathrm{~m}_{2} ; \text { 係数 }\right)
$$

調査地区 4 を例にして述べる。表 1 ，表 2 および表 3 より調査地 区 4(T4)は, $\mathrm{G}+\mathrm{n} \cdot \varepsilon=32458, \mathrm{a}_{1}=0.0186, \mathrm{c}_{1}=186, \ldots \mathrm{m}_{1}=1.58, \mathrm{~m}_{2}=0.631$ であるから，式(4)および式(5)より $V_{\text {mean }}(\mathrm{m} / \mathrm{min})$ は式(9) となる。 
表 3 各調査地区の火面周長の係数 $\mathrm{m}_{1}, \mathrm{~m}_{2}$

\begin{tabular}{|c|c|c|c|}
\hline 調查地区 & $\mathrm{m}_{1}$ & $\mathrm{~m}_{2}$ & 重相関係数 $: R$ \\
\hline $\mathrm{T} 1$ & 2.19 & 0.592 & 0.996 \\
\hline $\mathrm{T} 2$ & 1.42 & 0.634 & 0.985 \\
\hline $\mathrm{T} 3$ & 3.57 & 0.527 & 0.947 \\
\hline $\mathrm{T} 4$ & 1.58 & 0.631 & 0.993 \\
\hline $\mathrm{T} 5$ & 0.15 & 0.846 & 0.979 \\
\hline $\mathrm{T} 6$ & 1.93 & 0.607 & 0.996 \\
\hline $\mathrm{T} 8$ & 7.89 & 0.421 & 0.953 \\
\hline
\end{tabular}

$V_{\text {men }}=\mathrm{a}: \cdot A(1-A /(\mathrm{G}+\mathrm{n} \cdot \varepsilon)) /\left(\mathrm{m} \cdot A^{\mathrm{m} 2}\right)$

$=0.0186 \cdot A(1-A / 32,458) / 1.58 \cdot A^{0.53}$

32,458

32,458

$A=$

$1-\mathrm{e}^{-0.0188(x-186)}$

$1-\mathrm{e}^{0.0186 \times 186}$

次に, 図 2 に $V_{\max }$ (実測) とその時の $V_{\operatorname{men}}$ の関係を示っすが, $V_{\max }$ (予 測)を式 (10)のように直線の場合と式(11)のように指数関数で表現 する方法を検討した。

$V_{\text {max }}($ 予測 $)=\mathrm{M} \cdot V_{\mathrm{mean}} \quad($ ここ, $\mathrm{M}$; 補正係数 $)$

$V_{\mathrm{m} 2 \mathrm{x}}($ 予測 $)=\mathrm{M}_{1} \cdot V_{\mathrm{menn}}{ }^{{ }^{\mathrm{M}} 2} \quad\left(こ こ に \mathrm{M}_{1}, \mathrm{M}_{2} ;\right.$ 補正係数 $)$

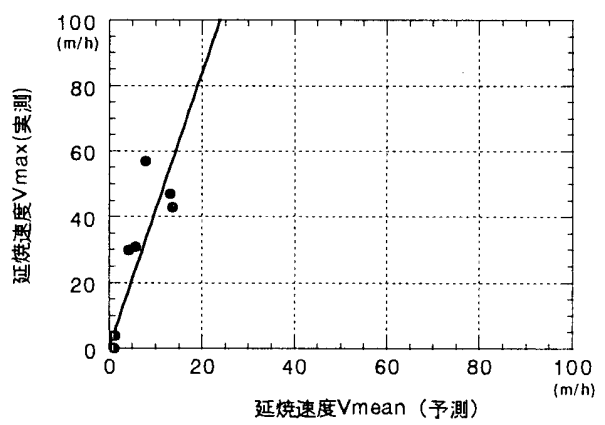

図 2 延焼速度 $V_{\max }$ (実測) と $V_{\text {mean }}$ の関係 $(\mathrm{T} 4)$

調査地区 4(T4)の場合は $\mathrm{M}=4.19$ (重相関係数 ; $\mathrm{R}=0.789$ ) となり, 各時間ごとの $V_{\max }($ 予測 $)=\mathrm{M} \cdot V_{\operatorname{mean}}$ を図 3 の(2)としてに描いている。 また， $V_{\operatorname{man}}$ は(1)として描いている。

各調査地区について, 以上のような計算をした結果を表 4 に示し ている。表 4 に示すように実測値と式（10）による予測值の重相関係 数は, 約 $0.94 \sim 0.73$ である。なお, 相関係数によって比較的強い 創刊を示すことがわかるが，どの程度のばらつきがあるかを散布図 で確認するために, 全調查地区の全データについて $V_{\max }$ (実測) と $V_{\max }$ (予測)の関係を図 4 に示している。

次に, 式(11)の指数関数の場合の重相関係数は, 約 $0.95 \sim 0.73$ である。このように両者の相関係数は，ほとんど差がない。指数関

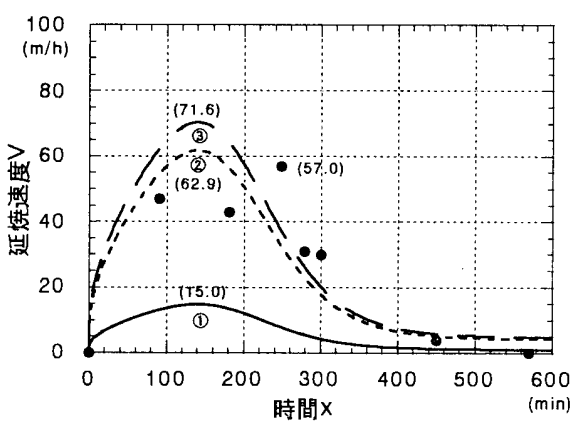

図 3 延焼速度と時間の関係 (T4)

表 4 各調査地区の延焼速度の補正係数

\begin{tabular}{|c|c|c|c|c|c|c|c|}
\hline 調査地区 & $\mathrm{T} 1$ & $\mathrm{~T} 2$ & $\mathrm{~T} 3$ & $\mathrm{~T} 4$ & $\mathrm{~T} 5$ & $\mathrm{~T} 6$ & $\mathrm{~T} 8$ \\
\hline 補正係数 : M & 5.33 & 3.54 & 3.83 & 4.19 & 3.94 & 5.00 & 2.54 \\
\hline 重相関係数 : $\mathrm{P}$ & 0.854 & 0.737 & 0.730 & 0.789 & 0.943 & 0.896 & 0.820 \\
\hline 補正係数 : $\mathrm{M}_{1}$ & 2.24 & 5.56 & 3.95 & 10.7 & 3.13 & 7.08 & 8.49 \\
\hline 補正係数 : $\mathrm{M}_{2}$ & 1.42 & 0.769 & 0.983 & 0.607 & 1.09 & 0.871 & 0.626 \\
\hline 重相関係数 : R & 0.874 & 0.753 & 0.730 & 0.869 & 0.945 & 0.901 & 0.891 \\
\hline
\end{tabular}

数の場合には， $\mathrm{M}_{1}$ および $\mathrm{M}_{2}$ の初期值の与え方によっては収束しな い場合もあるので，式(10)を使用して $V_{\text {max }}$ (予測)の予測をしてもよ いと思われる。

次に, 各調査地区における各種延焼速度の時間変動に対する最大 值について比較する。すなわち， $V_{\text {max }}$ (実測)の最大値， $V_{\text {mean }}$ の最大 值およびその時の予測值 $\left(V_{\max }\right.$ (予測 $\left.)\right)$ の最大值を表 5 に示すが，平 均の闌をみると, $V_{\text {max }}($ 実測 $)=65.7 \mathrm{~m} / \mathrm{h}$ である。 $V_{\max }($ 予測 $)$ は, $\mathrm{M} \cdot V_{\text {mean }}$ $=62.9 \mathrm{~m} / \mathrm{h} \quad\left(V_{\text {mean }}=16.6 \mathrm{~m} / \mathrm{h}\right)$ であり, $V_{\max }($ 実測 $)$ と $V_{\max }($ 予測 $)$ の平均値は かなりよく一致している。そして, 表 5 の $V_{\text {max }}$ (実測) の最大值と $V_{\text {max }}$ (予測) の最大值の相関係数は, 図 5 に示すように 0.902 である。

ところで, 図 3 には各時間ごとの実測值の最大值 (○記号) で示し ているが，時間間隔は一定ではない。すなわち，データが一定間隔 でないために資料収集が不十分で，もっと大きな值の実測值を収集 していない可能性がある。したがって，実測值のほぼ最大值「 $V_{\text {max }}$ （実 測；2 $\sigma) 」$ を計算する。 0 は標準偏差である。図 3 に示す各調査 地区の実測データ(の記号)より各時間ごとの実測值の最大值の平均 值 $\left(\overline{\boldsymbol{V}}_{\mathrm{max}}(\right.$ 実測 $\left.)\right)$ ，標隻偏差 $\sigma$ を計算し，実測値のほぼ最大値「 $V_{\max }$ (実 測 $; 2 \sigma)\rfloor=\left[\bar{V}_{\max }(\right.$ 実測 $\left.)+2 \sigma\right]$ を求めたものを表 5 の $V_{\max }$ (実測 ;2 0 )として記入し, 図 3 の(3に示している。記号の実測值の 分布が正規分布である場合は，ほぼ $95 \%$ の実測値が $\bar{V}_{\max }($ 実測 $) \pm 2$ $\sigma$ の間に入ることが知られている ${ }^{17)}$ 。例えば，調査地区 4(T4）の場 合は $\bar{V}_{\max }($ 実测 $)+2 \sigma=26.5+2 \times 22.6=71.6 \mathrm{~m} / \mathrm{h}$ となる。(3)は, $V_{\text {max }}$ (実

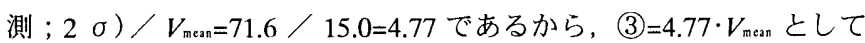
描いている。このように調査地区 4（T4）は $V_{\text {max }}$ (実測) $\fallingdotseq 57.0 \mathrm{~m} / \mathrm{h}$ であったが， $V_{\max }($ 予測 $) \fallingdotseq 62.9 \mathrm{~m} / \mathrm{h} ， V_{\max }$ (実測 $\left.; 2 \sigma\right) \fallingdotseq 71.6 \mathrm{~m} / \mathrm{h}$ の 可能があるとして図 3 に示している。他の調査地区も同様に計算し, 表 5 に示している。

次に, 全調查地区について $V_{\max }($ 予測 $)$ と $V_{\text {mean }}$ との関係を非線型最 小 2 乗法で計算した結果を式(12.1) 〜式 (12.3)に示す。（12.2）は, すべてのデータからの回帰式であり，ほぼ中央を描くので，変数の 前に下つき添字を用いて ${ }_{\mathrm{men}} V_{\mathrm{max}}$ (予測) と表示する。（12.1）および式 (12.3) は，ほぼ最大值および最小值を描いて求めたもので，同様に 


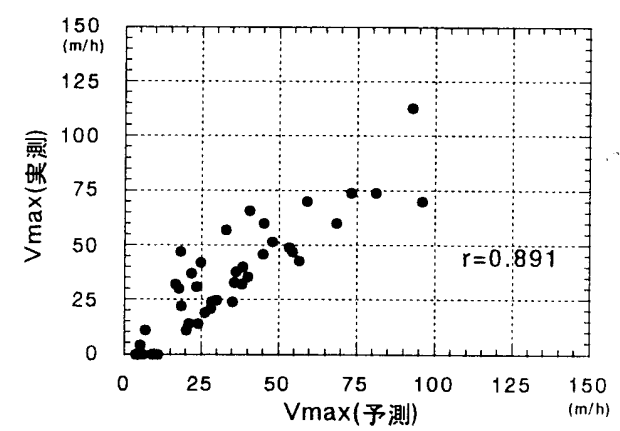

図 $4 V_{\max }($ 実測 $)$ と $V_{\max }($ 予測 $)$ の関係
$V_{\text {max }}$ (実測) $), V_{\text {menn }}, \quad V_{\text {max }}($ 予測 $) ， \quad V_{\text {max }}($ 実測 $; 2 \quad \sigma)$ の最大値

\begin{tabular}{|c|c|c|c|c|}
\hline $\begin{array}{c}\text { 調查 } \\
\text { 地区 }\end{array}$ & $V_{\text {max }}$ (実測) & $\begin{array}{c}V_{\text {mean }} \\
\text { (予測) } \\
(1)\end{array}$ & $\begin{array}{c}V_{\text {max }} \\
\text { (予測) } \\
(2)\end{array}$ & $\begin{array}{c}V_{\text {max }} \\
\text { (実測 ; } \\
(3)\end{array}$ \\
\hline T1 & 66.0 & 10.5 & 56.0 & 76.2 \\
\hline T2 & 37.0 & 8.03 & 28.4 & 44.7 \\
\hline T3 & 42.0 & 8.00 & 30.0 & 46.9 \\
\hline T4 & 57.0 & 15.0 & 62.9 & 71.6 \\
\hline T5 & 70.0 & 18.0 & 70.6 & 99.2 \\
\hline T6 & 114 & 20.0 & 100 & 120 \\
\hline T8 & 74.0 & 36.5 & 92.7 & 96.2 \\
\hline 平均 & 65.7 & 16.6 & 62.9 & 79.3 \\
\hline
\end{tabular}

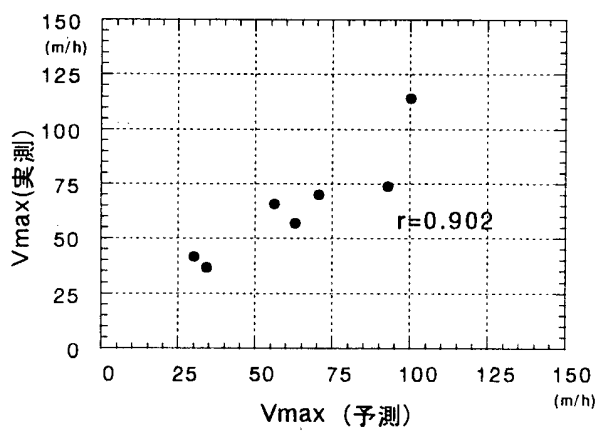

図 $5 V_{\max }($ 実測 $)$ の最大值と $V_{\max }$ (予測)の最大值の関係

${ }_{\max } V_{\max }\left(\right.$ 予測) および ${ }_{\text {min }} V_{\max }$ (予測) と表示する。

${ }_{\text {max }} V_{\max }($ 予測 $)=11.2 \cdot V_{\text {mena }}{ }^{0.735}$

${ }_{\operatorname{menan}} V_{\text {max }}($ 予測 $)=7.06 \cdot V_{\text {mean }}^{0.785}$

${ }_{\text {min }} V_{\text {max }}($ 予測 $)=3.48 \cdot V_{\text {mean }}^{0.885}$

さらに，全調査地区について $V_{\max }$ (実測) と $V_{\text {mean }}$ との関係を図 6 に 示し，その関係を非線形最小 2 乗法で計算した結果を式 (13.1) 〜式 （13.3）に示す。図6にはこれらの曲線および式 (12.1)〜式 (12.3)を 描いている。なお，前式同様に式(13.2)は，すべてのデータからの 回帰式であり，ほぼ中央を描くので, $\operatorname{men} V_{\max }$ (予測) と表示する。式 (13.1) および式 (13.3)は，ほぼ最大值および最小值を描いて求めた

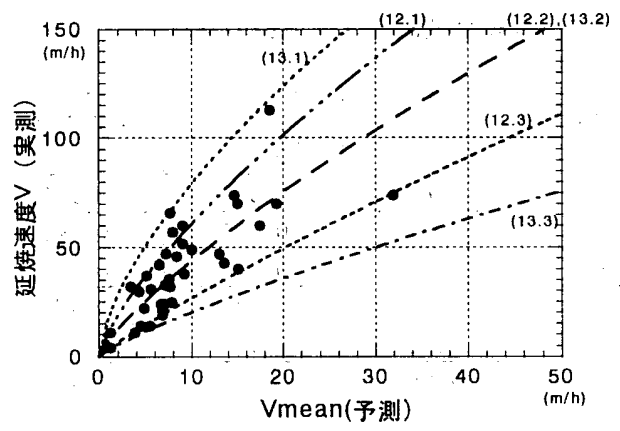

図 6 延焼速度 $V_{\max }$ (実測) と $V_{\operatorname{mena}}$ の関係

もので, ${ }_{\text {MAx }} V_{\text {max }}($ 予測 $)$ および ${ }_{\text {MIN }} V_{\text {max }}($ 予測 $)$ と表示する。

$$
\begin{aligned}
& { }_{4 \times x} V_{\max }(\text { 実測 })=17.9 \cdot V_{\text {mexan }}^{0.645} \\
& { }_{\operatorname{men}} V_{\max }(\text { 実測 })=7.21 \cdot V_{\text {mean }}^{0.783} \\
& { }_{\text {MIN }} V_{\max }(\text { 実測 })=3.09 \cdot V_{\operatorname{mean}}{ }^{0.818}
\end{aligned}
$$

表 6 には ${ }_{\max } V_{\max }$ (予測) : 式(12.1) と ${ }_{4} \times V_{\max }$ (実測) : 式(13.1), ${ }_{\text {mens }} V_{\max }$ (実測)：式(13.2)の最大値を表示している。また, ${ }_{\text {MAx }} V_{\max }$ (実 測)および ${ }_{\text {Min }} V_{\text {max }}$ (実測)によって兵庫県南部地震による神戸市内の 延焼速度（実測值）の最大値および最小值の概略値が求まる。そし

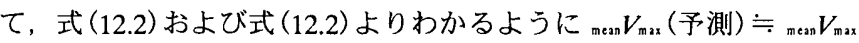
(実測)である。式(13.2)より計算した結果は表 6 に: men $_{\max } V_{\max }$ (実測) と して示しているが, $V_{\text {max }}$ (予測)：(2)の最大值と ${ }_{\operatorname{man}} V_{\max }$ (実測)：式 (13.2) の最大値を比較すると, 平均值は $62.9 \mathrm{~m} / \mathrm{h}$ と $63.4 \mathrm{~m} / \mathrm{h}$ であり, ほぼ一致している。相関係数は図 7 に示すように 0.837 である。し たがって， $V_{\max }$ (予測) は式(13.2)の ${ }_{\operatorname{men}} V_{\max }$ (実測)でほぼ求まると思わ れる。 $V_{\max }\left(\right.$ 実測 $; 2 \sigma$ ) : (3)の最大值と $V_{\max }$ (予測) : (2)の最大值との 相関倸数は，図 8 に示すように 0.957 であるので, $V_{\max }$ (実測 $; 2 \sigma$ ) は， $V_{\max }($ 予測)でほぼ求められると思われる。以上のように, 全体 のデータによって比較的高い相関係数があることがわかうたので, $V_{\max }($ 実測 $)$ と $V_{\max }\left({ }^{3}\right.$ 測 $)$ の関係, $V_{\max }($ 予測 $)$ と $\operatorname{men}_{\max } V_{\operatorname{ma}}$ (実測)の関係並 びに $V_{\max }($ 実測 $; 2 \sigma)$ と $V_{\max }$ (予測)の関倸について以下のような定 式化を試みる。この場合，原点を通る直線，任意の直線および指数 関数（べき乗関数）の 3 種類を仮定して，これらの数式による直線 ・曲線と寒測值との隔たり・乘離が具体的にどの程度あるかを検討 する。このように数式化・グラフ化しておくことは地震時のような 情報の少ない状況の下で延焼速度を予測する場合に有効と考えられ るからである。

$V_{\max }($ 実測 $)=0.999 \cdot V_{\max }($ 予測 $) \quad ＼quad （ \mathrm{R}=0.890 ）$

(14.1)

$V_{\max }($ 実測 $)=0.968 \cdot V_{\max }($ 予測 $)+1.58 \quad ＼quad(\mathrm{R}=0.891)$

$V_{\text {max }}($ 実測 $)=1.49 \cdot V_{\text {max }}(\text { 予測 })^{0.901} \quad （ \mathrm{R}=0.894 ）$

$V_{\text {max }}($ 予測 $)=0.997 \cdot_{\text {maxn }} V_{\max }($ 実測 $) ＼quad(\mathrm{R}=0.920)$

$(15.1)$ 
表 6

$V_{\max }$ (予測) ${ }^{m e a n} V_{\max }$ (実測)および ${ }_{\text {Mx }} V_{\max }$ (実測)の最大值

\begin{tabular}{|c|c|c|c|}
\hline $\begin{array}{c}\text { 調查 } \\
\text { 地区 }\end{array}$ & $\begin{array}{c}\max V_{\max } \\
\text { (予測) } \\
\text { 式(12.1) }\end{array}$ & $\begin{array}{c}\text { mean } V_{\max } \\
\text { (英測) } \\
\text { 式(13.2) }\end{array}$ & $\begin{array}{c}\text { MAX } V_{\max } \\
\text { (実測) } \\
\text { 式(13.1) }\end{array}$ \\
\hline T1 & 63.1 & 45.4 & 81.6 \\
\hline T2 & 51.8 & 36.2 & 68.6 \\
\hline T3 & 51.6 & 36.7 & 68.4 \\
\hline T4 & 82.0 & 60.1 & 103 \\
\hline T5 & 93.7 & 69.3 & 115 \\
\hline T6 & 101 & 75.3 & 124 \\
\hline T8 & 156 & 121 & 182 \\
\hline 平均 & 85.6 & 63.4 & 106 \\
\hline
\end{tabular}

(単位 : $m / h$ )

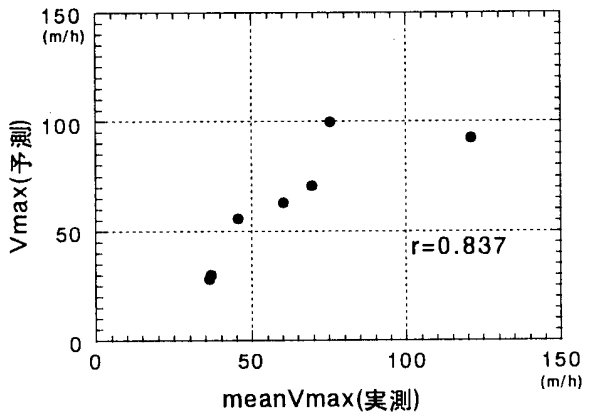

図 7 延焼速度 $V_{\max }$ (予測)の最大值之 ${ }_{\operatorname{men}} V_{\mathrm{max}}$ (実測)の最大值の関係

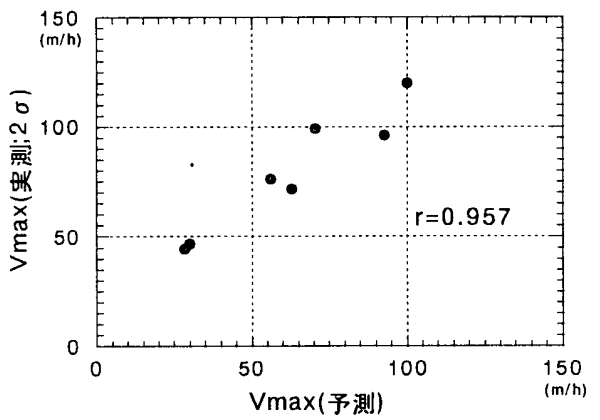

図 $8 V_{\max }$ （実測；2 $\sigma ）$ の最大值と $V_{\max }$ （予測）の最大值の関係

$$
\begin{aligned}
& V_{\text {max }}(\text { 予測 })=1.04{ }^{\text {mean }} V_{\text {max }}(\text { 実測 })-3.11 \quad ＼quad(\mathrm{R}=0.923 ） \\
& V_{\max }(\text { 予測 })=0.917 \cdot_{\text {mean }} V_{\max }(\text { 実測 })^{1.02} \quad ＼quad(\mathrm{R}=0.920 ） \\
& V_{\text {max }}(\text { 実測 } ; 2 \sigma)=1.22 \cdot V_{\text {max }}(\text { 予測 }) \quad ＼quad(\mathrm{R}=0.915 ） \\
& V_{\text {max }}(\text { 実測 } ; 2 \quad \sigma)=0.958 \cdot V_{\text {max }}(\text { 予測 })+19.0 \quad(\mathrm{R}=0.957) \\
& V_{\text {max }}(\text { 実測 } ; 2 \sigma)=3.86 \cdot V_{\text {max }}(\text { 予測 })^{0.734} \quad(\mathrm{R}=0.958)
\end{aligned}
$$

$(16.1)$

次に, 以上の式 (14.1) 〜式 (16.3) と表 7 についてより詳細に検討 する。そして，どの式が適当であるかについては，種々の基準が考 えられるが，次の基準を考慮することにする。

（1）重相関係数がより大きいこと

（2）平均值がほぼ一致すること

（3）各予測値と各実測値の差を次の 3 段階に分類し, より実測値
に近い值を示す式を選定する。

I . 実測値との割合が $20 \%$ 以上〜 $30 \%$ 未満小のもの（ $\nabla$ 記号） および大のもの（ $\triangle$ 記号）

II. 実測値との割合が $30 \%$ 以上〜 $50 \%$ 末満小のもの（記号） および大のもの（A記号）

III. 実測值との割合が $50 \%$ 以上小のも（†記号）および大の もの（†記号）

そして，表 7 に示す数值は， $V_{\max }$ (実測) : (f) (h) : 式 (14.1) 式 (14.3) と $V_{\max }($ 予測 $):(\mathrm{c}) \sim(\mathrm{e}):$ 式 (15.1) 〜式 (15.3)の場合には, $V_{\max }$ (実測)：(a)を基準（1.00）として，それぞれの数値の割合〔(c)/ (a) 〜 (h) /(a) \} を示している。

また, $V_{\max }($ 奏測 $; 2 \sigma) ：(1) \sim(\mathrm{n}):$ 式 $(16.1) \sim$ 式 (16.3)の場合 は， $V_{\max }($ 実測；2 $\sigma$ ）:(k): (3)を基準（1.00）として，それぞれ の数值の割合 $((\mathrm{l}) /(\mathrm{k}) \sim(\mathrm{n}) /(\mathrm{k}))$ を示している。

$V_{\max }($ 予測 $)=\mathrm{M} \cdot V_{\operatorname{mean}}$ : (2)を代入して $V_{\max }$ (実測) を求める式 (14.1) 〜式 (14.3)の場合は，それぞれの重相関係数と割合の値を比較する と, 式 (14.1) は重相関係数 $\mathrm{R}=0.890$, (f) /(a)=0.957 であり, 式 (14.2) は $\mathrm{R}=0.891,(\mathrm{~g}) /(\mathrm{a})=0.951$, 式 $(14.3)$ は $\mathrm{R}=0.894,(\mathrm{~h}) /(\mathrm{a})=0.947$ となっており，ほほ差がない。式(14.1)の場合に調査地区 T2 (0.767, $\nabla), \mathrm{T} 3(0.714, \nabla), \mathrm{T} 8(1.25, \nabla)$, 式 (14.2) の場合に調查地区 T3 $(0.731, \nabla), \mathrm{T} 8(1.23, \triangle)$ および式(14.3)の場合に T3（0.760, V) が， $V_{\text {max }}$ (実測）と $20 \sim 30 \%$ の割合で離れているが， $30 \%$ 以 上の承離はない。したがって, 式(14.2) と式(14.3)が, より適当で あると考えられる。しかし, 式(14.2)の場合は $V_{\max }$ (予測) が 0 に 近くなると, $V_{\max }$ (実測) $\fallingdotseq 1.58 \mathrm{~m} / \mathrm{h}$ と一定值を示すので, 式 (14.3) がより適当であろう。式(14.3)の場合を図 9 に示す。

次に, $V_{\text {max }}$ (実測 ; $2 \sigma$ ) : (3)と $V_{\text {max }}$ (予測) $=\mathbf{M} \cdot V_{\text {mean }}$ : (2)の関係 を表す式(16.1)～式(16.3)の場合について検討する。式 (16.1) は R $=0.915,(\mathrm{l}) /(\mathrm{k})=0.968$ であり, T2 $(0.775, \nabla), \mathrm{T} 3(0.780, \nabla)$ が $20 \sim 30 \%$ 割合で離れている。さらに，それぞれの重相関係数 と割合の値を比較すると, 式 (16.2) は $\mathrm{R}=0.957,(\mathrm{~m}) /(\mathrm{k})=0.994$ と なっており，式(16.3)は $\mathrm{R}=0.958 ，(\mathrm{n}) /(\mathrm{k})=1.02$ である。式(16.2) の場合は $V_{\max }$ (予測) が 0 に近くなると $V_{\max }$ (実測 $\left.; 2 \sigma\right) \fallingdotseq 19.0 \mathrm{~m} / \mathrm{h}$ と一定值を示すので, 式 (16.3)がより適当であろう。式(16.3)の場 合を図 10 に示す。

次に, $V_{\max }($ 予測 $)=\mathrm{M} \cdot V_{\text {mean }}$ ：(2) と ${ }_{\operatorname{mean}} V_{\max }$ (実測): 式 (13.2)の 関係を表す式(15.1)～式(15.3)について検討する。式(15.1)は $\mathrm{R}=$ 0.920, (c)/(a)=0.943) であり, T1 $(0.672, \boldsymbol{\nabla}), \mathrm{T} 6(0.645, \boldsymbol{\nabla}), \mathrm{T} 8$ $(1.60, \uparrow)$ となっている。式 (15.2)の場合は, $\mathrm{R}=0.923,(\mathrm{~d}) /(\mathrm{a})=0.956$

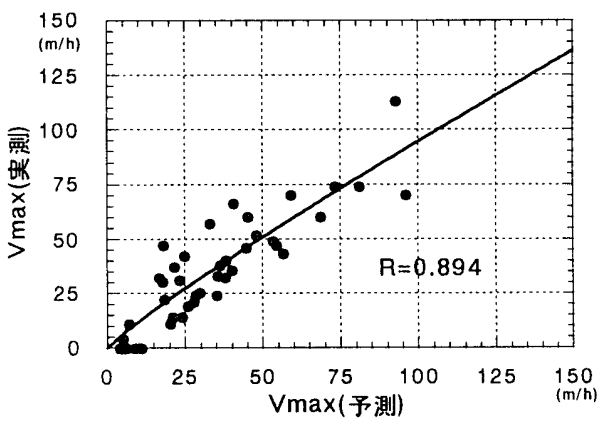

図 9 延焼速度 $V_{\text {max }}$ (実測) と $V_{\max }($ 予測)の関係 
表7 $V_{\text {max }}$ (実測)， $V_{\max }$ (実測 $\left.; 2 \sigma\right) ， V_{\max }($ 予測 $)$ および $V_{\max }$ (実測)の最大值

\begin{tabular}{|c|c|c|c|c|c|c|c|c|c|c|c|c|c|c|c|c|c|c|c|c|}
\hline \multirow[t]{2}{*}{$\begin{array}{l}\text { 调查 } \\
\text { 地区 }\end{array}$} & \multirow{2}{*}{$\begin{array}{c}V_{\max } \text { (英測) } \\
\text { (a) }\end{array}$} & \multirow{2}{*}{$\begin{array}{c}(3): V_{\max } \\
\text { (英測 } ; 2 \sigma) \\
(\mathrm{k})\end{array}$} & \multicolumn{2}{|c|}{$\begin{array}{c}\mathrm{V}_{\max } \text { (英測；2 } \\
\text { 式(16.1) }\end{array}$} & \multicolumn{2}{|c|}{$\begin{array}{c}\left.v_{\max } \text { (实測; } 2 \sigma\right) \\
\text { 式(16.2) }\end{array}$} & \multicolumn{2}{|c|}{$\begin{array}{c}v_{\text {max }}(\text { 实測 ; } 20) \\
\text { 式 }(16.3)\end{array}$} & \multicolumn{2}{|c|}{$\begin{array}{c}V_{\max }(\text { 予測 }) \\
\text { 式(15.1) }\end{array}$} & \multicolumn{2}{|c|}{$\begin{array}{c}V_{\max }(\text { 予測 }) \\
\text { 式(15.2) }\end{array}$} & \multicolumn{2}{|c|}{$\begin{array}{c}V_{\max } \text { (予測) } \\
\text { 式(15.3) }\end{array}$} & \multicolumn{2}{|c|}{$\begin{array}{l}\mathrm{V}_{\max } \text { (英測) } \\
\text { 式(14.1) }\end{array}$} & \multicolumn{2}{|c|}{$\begin{array}{l}\mathrm{V}_{\max } \text { (英測) } \\
\text { 式(14.2) }\end{array}$} & \multicolumn{2}{|c|}{$\begin{array}{c}\mathrm{V}_{\max } \text { (英測) } \\
\text { 式(14.3) }\end{array}$} \\
\hline & & & (1) & $(1) /(\mathrm{k})$ & (m) & $(\mathrm{m}) /(\mathrm{k})$ & (n) & $(n) /(k)$ & (c) & $(c) /(a)$ & (d) & $(d) /(a j$ & (e) & $(\mathrm{e}) /(\mathrm{a})$ & (f) & $(f) /(a)$ & $(\mathrm{g})$ & $(\mathrm{g}) /(\mathrm{a})$ & (h) & $(h) /(a)$ \\
\hline $\mathrm{T} 1$ & 66.0 & 76.2 & 68.3 & 0.897 & 71.6 & 0.940 & 74.1 & 0.972 & 44.4 & $0.672 \nabla$ & 44.1 & $0.668 \nabla$ & 44.9 & $0.681 \nabla$ & 55.9 & 0.848 . & 55.7 & 0.844 & 56.0 & 0.849 \\
\hline $\mathrm{T} 2$ & 37.0 & 44.7 & 34.6 & $0.775 \nabla$ & 46.2 & 1.03 & 45.0 & 1.01 & 35.4 & 0.956 & 34.5 & 0.933 & 35.7 & 0.964 & 28.4 & $0.767 \nabla$ & 29.9 & 0.808 & 30.4 & 0.821 \\
\hline T3 & 42.0 & 46.9 & 36.6 & $0.780 \nabla$ & 45.8 & .977 & 46.9 & 0.999 & 35.9 & 0.854 & 35.1 & 0.835 & 36.2 & 0.861 & 30.0 & $0.714 \nabla$ & 30.7 & $0.731 \nabla$ & \begin{tabular}{|l|}
31.9 \\
\end{tabular} & $0.760 \nabla$ \\
\hline T4 & 57.0 & 71.6 & 76.7 & .07 & 8.5 & 10 & 80.7 & 13 & 58.7 & 1.03 & 59.4 & 1.04 & 59.8 & 1.05 & 62.8 & 1.10 & 62.4 & 1.09 & 62.2 & 1.09 \\
\hline T5 & 70.0 & 99.2 & 86.1 & 0.868 & 86.1 & 0.868 & 87.8 & 0.885 & 67.7 & 0.967 & 69.0 & 0.985 & 69.2 & 0.988 & 70.5 & 1.01 & 69.8 & 0.997 & 69.0 & 0.986 \\
\hline T6 & 114 & 120 & 122 & 1.02 & 115 & 0.958 & 113 & 0.945 & 73.6 & $0.645 \nabla$ & 75.2 & $0.660 \nabla$ & 75.3 & $0.660 \nabla$ & 99.9 & 0.876 & 98.1 & 0.861 & 94.4 & 0.828 \\
\hline T8 & 74.0. & 96.2 & 113 & 1.18 & 108 & 1.12 & 107 & 1.11 & 118.2 & $1.60 \mathrm{t}$ & 122.7 & $1.66 \mathbf{t}$ & 122.1 & $1.65 \mathbf{t}$ & 92.6 & $1.25 \triangle$ & 91.1 & $1.23 \triangle$ & 88.2 & 1.19 \\
\hline 平均 & 65.7 & 79.3 & 76.8 & 0.968 & 78.8 & 0.994 & $80.7 \mid$ & 1.02 & 61.9 & 0.943 & 62.8 & 0.956 & 63.2 & 0.961 . & 62.9 & 0.957 & 62.5 & 0.951 & 62.2 & 0.947 \\
\hline
\end{tabular}

(単位: $\mathrm{m} / \mathrm{h}$ )

であり, T1 $(0.668, \boldsymbol{\nabla}), \mathrm{T} 6(0.660, \boldsymbol{\nabla}), \mathrm{T} 8(1.66, \boldsymbol{\uparrow})$ となっ ている。式(15.3)は, R=0.920，(e)/(a)=0.980) であり, T1 (0.681, $\boldsymbol{\nabla}), \mathrm{T} 6(0.660, \boldsymbol{\nabla}), \mathrm{T} 8(1.65, \boldsymbol{\uparrow})$ となっており, 式(15.3)がや やよい。また; それぞれの重相関係数と割合の値を比較するとほと んど差がないが，式(15.3)が最も高い。以上のことから，式(15.1) 〜式(15.3)の中では, 式(15.3)がより適当であると考えられる。式 (15.3)の場合を図 11 に示す。

また, $V_{\max }$ (実測)：(a)を求める式 (14.1)〜式(14.3)および $V_{\max }$ (実 測；2 $\sigma$ ) : (3)を求める式(16.1)〜式(16.3)において, 式(10)より求 めた $V_{\max }$ (予測) : (2)を代入するかわりに, 式 (15.1) 〜式 (15.3) の ${ }_{\operatorname{mean}} V_{\max }$ (実測)に式 (13.2) を適用して求まる $V_{\max }$ （実測）を代入して 求めてもよい。

次に, 図 12 に調查地区 4(T4)の場合の $V_{\max }$ (実測), $V_{\text {mean }}$, 式 (14.3)： (11)よび式(16.3):(13)を示す。図 12 のように，(11)は実測値のほぼ中 間に位置する。また，(13は図 3 の(3)と比較すると違いがよくわかる が，実測值のほぼすべてを包含するように描かれている。

\section{4. 結論}

本研究で得られた結論をまとめると以下のようである。

（1）各調查地区に対して，焼損面積 $A$ 抽よび火面周長 $S_{\text {man }}$ の式よ り延焼速度 $V_{\text {mean }}$ を求めることができる。

$V_{\max }$ (予測) を求めるには， $V_{\text {mean }}$ に一次式で求めた補正係数 $\mathrm{M}$ を 利用した式(10)と，指数関数で求めた補正係数 $\mathrm{M}_{1}, \mathrm{M}_{2}$ を利用した 式(11)がある。表 4 に示す通り, 両者の相関倸数に大きな差はない。 したがって，式(10)を使用して予測することができる。

（2） 全調查地区の ${ }_{\text {max }} V_{\max }$ (予測)， ${ }_{\operatorname{maran}} V_{\max }$ (予測)， ${ }_{\text {min }} V_{\max }$ (予測) と $V_{\text {mean }}$ との関係を式 (12.1)〜式 (12.3)に示した。同様に, ${ }_{\text {MAx }} V_{\text {max }}$ （実 測 $),{ }_{\operatorname{men}} V_{\max }$ (実測),${ }_{\text {MIN }} V_{\max }$ (実測) と $V_{\operatorname{mean}}$ との関係を図 6 と式 (13.1) 〜式(13.3)に示した。

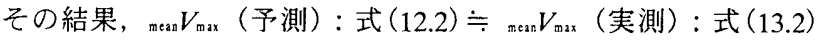
である。また, 式(13.1)および式 (13.3) で示す ${ }_{\text {MAx }} V_{\max }$ (実測) およ び ${ }_{\text {}}{ }_{\mathrm{N}} V_{\max }$ （実測）によって, 兵庫県南部地震の神戸市内の延焼速度 （実測值）による最大值および最小値が示される。

（3）表 5 , 表 6 および表 7 に示すように全調査地区の平均を比較 すると, $\operatorname{mean}_{\max }$ (実測) と $V_{\max }$ (予測) はほぼ一致した。したがっ て, $V_{\max }$ (予測) は mean $_{\max }$ (実測): 式 (15.3)でほぼ求まる。

また, 式(14.1) 〜式(16.3)においては, 重相関係数と, 各予測値 の平均および各実測值との割合をとったもので判断した。

その結果， $V_{\max }$ (実測)， $V_{\max }$ (予測)および $V_{\max }$ (実測 ; $2 \sigma$ )を

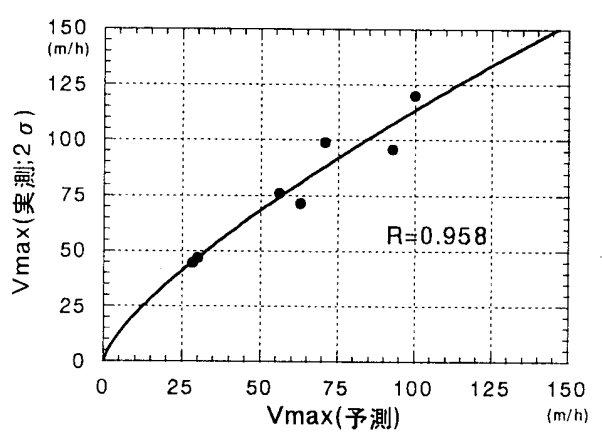

図 $10 V_{\text {max }}$ (実測 ; $\left.2 \sigma\right)$ の最大値と $V_{\max }$ (予測) の最大值の関係

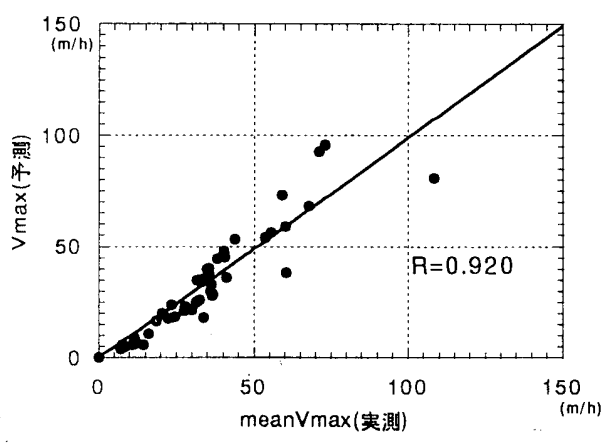

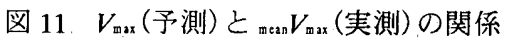

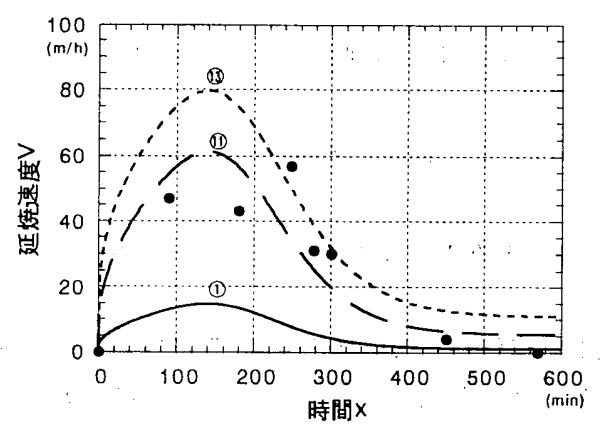

図 12 延焼速度之時間の関係 (T4) 
求める場合は，それぞれ指数関数で表した式(14.3), 式(15.3)およ び式(16.3)が, より適当であると考えられる。これらの主な関係に ついて，調査地区 4 の場合を図 12 に示した。

今後は, 阪神大震災の解析だけではなく, 同じく直下型地震とい われる福井地震, また平常時大火（昭和 21 年〜昭和 27 年）等を解 析し，比較検討を行う必要があると思われる。

なお, 非線形最小 2 乗法の計算は主として, 株式会社ヒューリン クス製の KALEIDAGRAPH-J（バージョン 3.05, マッキントッシュ 版）によった。

\section{謝辞}

この研究に際し, ご協力して頂いた建設省建築研究所, 消防庁消 防研究所, 東京消防庁並びに神戸市消防局に感謝の意を表する次第 である。

\section{参考文献}

1) 東京消防研究會 : 火災に於ける延烓速度, pp.3 4, 東京消防研究會, 1942

2）内田祥文: 建築と火災, p.120, 相模書房, 1953

3）䏱内三郎ほか: 新版建筇防火, pp.178 230, 朝倉書店, 1994

4）保野健治郎ほか：ロジスティック曲線による建物火災の延娃速度式に関 する基整的研究，日本建築学会論文報告集，No.311，pp.137～144，1982

5）保野健治郎ほか：建物火炎の延娔に関する基礎的研究，日本火災学会論 文報告集，Vol.32，No.1，pp.23 32，1982

6）保野健治郎ほか：定差図法による建物火災の延㷬速度式（ロジスティッ
ク曲線）に関する基礎的研究，日本建策学会論文報告集，No.311，pp.155 $\sim 160,1982$

7）保野健治郎ほか：建物火災の放水による延娃阻止効果に関する基礎的研 究, 日本火災学会論文集, Vol.32, No.2, pp.57〜65, 1982

8）保野健治郎ほか：建築火災之消防水利に関する一考祭, 日本火災学会研 究発表会梗概集, pp.101 102, 1981

9）保野健治郎ほか：建筑火炎の消火と水損面積に関する基碤的研究，日本 建筑学会構造系論文報告集， No.422，pp.135～143，1991

10）保野健治郎ほか：市街地の建物火災に対応した消防水利計画に関する基 礎的研究，士木学会文集，No.425/IV-14, pp.145 153, 1991

11）保野健治郎：建物火炎の延焼速度式之所有消火水量に関する研究，日本 火災学会論文報告集，Vol.20， No.2，pp.55～63，1971

12）神戸市消防局編：阪神・淡路大震災における消防活動の記録 (神戸市域)， （財）神户市防災安全公社／東京法令出版株式会社, pp.141 161，1995

13）保野健治郎ほか：地震時火炎の延焼速度式に関する基礎的研究，日本火 災学会論文報告集, Vol.44, No.1·2, pp.15 23, 1996

14）保野健治郎ほか：地震時火災の延娃速度式と予測に関する基礎的研究， 日本建策学会計画系論文報告集， No.501，pp.9～16，1997

15）保野健治郎ほか：平常時および地震時火災の所要消防力と火面周長に関 する基街的研究, 日本火炎学会論文報告集, Vol.47, No.1·2, pp.1～12, 1997 16）保野健治郎ほか：地震時および強風下における市街地火災の延赎速度と 予測に関する基礎的研究, 日本火災学会論文報告集, Vol.48, No.1, pp.1 $\sim 10,1998$

17）松原望ほか：統計学入閒，東京大学出版会，p.262～264, 1991 